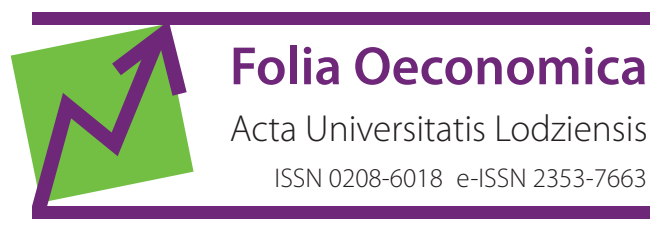

www.czasopisma.uni.lodz.pl/foe/

5(344) 2019

DOI: http://dx.doi.org/10.18778/0208-6018.344.10

\author{
Aneta Kuźniarska \\ Uniwersytet Jagielloński, Wydział Zarządzania i Komunikacji Społecznej \\ Instytut Ekonomii, Finansów i Zarządzania, aneta.kuzniarska@uj.edu.pl
}

\title{
Bariery implementacji controllingu w sieciach handlu detalicznego
}

Streszczenie: Głównym celem przeprowadzonych badań była identyfikacja czynników stanowiących barierę wdrażania controllingu w sieciach handlu detalicznego (na potrzeby artykułu terminy sieć handlu detalicznego oraz sieć handlowa stosowane będą zamiennie). Badanie ilościowe przeprowadzono za pomocą narzędzia badawczego, które stanowił kwestionariusz ankiety, zawierający pytania zamknięte, skierowany do pracowników sieci handlowych, głównie specjalistów z działów controllingu, HR, kierowników różnego szczebla oraz dyrektorów. Badania przeprowadzono w dużych sieciach z udziałem kapitału polskiego i zagranicznego. Ich wyniki wykazały, iż najistotniejszą barierę implementacji controllingu stanowi zbyt niski poziom wiedzy na temat sposobów wdrażania controllingu oraz brak odpowiedniego zaplecza finansowego umożliwiającego jego wdrożenie. Ze względu na hermetyczność sieci handlowych oraz fakt, iż do tej pory zajmowano się głównie barierami wdrażania controllingu w jednostkach produkcyjnych i usługowych, podjęty w artykule temat uznano za ważny.

Słowa kluczowe: bariery wdrażania controllingu, controlling, sieci handlowe

JEL: D22, M42 


\section{Wprowadzenie}

W myśl definicji Internationaler Controller Verein controlling stanowi proces zarządczy, którego zadaniem jest definiowanie celów, planowanie i sterowanie organizacją w sposób umożliwiający każdemu decydentowi działanie zorientowane na ustalony cel (https://www.icv-controlling.com/pl/o-controllingu/co-to-jest-controlling.html). P. Horvath (2006), T. Reichmann (2006) i H. Vollmuth (2007) określają controlling jako proces zarządzania, który - przez wspomaganie menedżerów informacjami ekonomicznymi - służy do poprawy jakości podejmowanych decyzji; to całość zadań, których celem jest zapewnienie dostępu do informacji i taka koordynacja działań w przedsiębiorstwie, która zapewnia optymalne osiągnięcie jego celów (Schweitzer, Friedl, 1992: 13) oraz ciągłe wyznaczanie celów nowych, realnych, uwzględniających otoczenie, kapitał i wnętrze organizacji (Eschenbach, 1990: 675). Postrzeganie controllingu jako elementu wsparcia menedżerów stanowi o jego zaletach, do których zaliczyć można między innymi: obniżanie kosztów, wzrost zysków i wydajności pracy, wypracowanie efektywnych strategii i struktur ułatwiających podejmowanie decyzji przez usprawnienie systemu informacji i obiegu dokumentów czy analizę rentowności kosztów w różnych obszarach funkcjonalnych przedsiębiorstwa (Goliszewski, 2015: 82). Może również decydować o częściowym sukcesie jego implementacji. Kompleksowe podejście do zadań controllingu pozwala na wyznaczanie przyszłych celów na podstawie informacji o trendach rynkowych i potrzebach klientów sieci handlowych, a także daje wiedzę na temat zjawisk zachodzących wewnątrz organizacji.

Controlling rozwija się z równym powodzeniem $\mathrm{w}$ firmach usługowych i produkcyjnych, w bankach, instytucjach użyteczności publicznej i administracji państwowej oraz w sieciach handlowych. Z punktu widzenia polskiej gospodarki sektor handlu stanowi ważny element gospodarki narodowej - po pierwsze ze względu na wysoką pozycję w tworzeniu PKB (w 2017 roku udział handlu w PKB wyniósł $15,3 \%$ ), po drugie ze względu na dominującą wśród jednostek usługowych rolę handlu jako pracodawcy (Rynek wewnętrzny..., 2017: 8-10). Działalność sieci handlowych ma duże znaczenie dla rozwoju miast i regionów - zarówno przez tworzenie miejsc pracy, jak i przez kreowanie funkcji architektonicznej, urbanistycznej oraz dochodowej i kulturowej. Rolą handlu jest przestrzenne i czasowe łączenie produkcji z konsumpcją towarów przez konsumenta końcowego (Seufert, 2014: 47).

Omawiany w artykule problem barier wdrożeniowych controllingu nie jest tematem nowym. Jednak dotychczasowe publikacje na ten temat obejmowały przedsiębiorstwa produkcyjne i usługowe (Fjałkowska, 2013; Janczyk-Strzała, 2013; Dynowska, 2015; Bieńkowska, Kral, Zabłocka, 2017; Kowalewski, Lelusz, 2018) oraz instytucje państwowe (Dynowska, 2015; Dynowska, Kes, 2016) z pominięciem przedsiębiorstw handlowych. Celem artykułu stało się zatem przybliżenie problemów (barier) wdrażania controllingu w sieciach handlowych. 
Na strukturę artykułu składa się opis roli controllingu z uwzględnieniem specyfiki zarządzania przedsiębiorstwem handlowym, opis barier wdrażania controllingu, zidentyfikowanych na podstawie wcześniej zrealizowanych badań w przedsiębiorstwach produkcyjnych i usługowych oraz opis metodologii i wyników badania empirycznego przeprowadzonego w sieciach handlowych.

\section{Rola controllingu w zarządzaniu przedsiębiorstwem handlowym}

W zależności od celów, jakie przedsiębiorstwo chce osiągnąć w dłuższym lub krótszym okresie oraz od rodzaju zaangażowanych do osiągnięcia tych celów zasobów, controlling może dotyczyć wszystkich obszarów działalności przedsiębiorstwa lub tylko wybranych podsystemów. W przypadku przedsiębiorstw handlowych najczęściej występujące obszary funkcjonowania controllingu to sfera finansów, zaopatrzenia, sprzedaży, logistyki, marketingu i zasobów ludzkich (por. Tabela 1).

Tabela 1. Wybrane obszary zastosowania controllingu w sieciach handlowych

\begin{tabular}{|l|l|}
\hline \multicolumn{1}{|c|}{$\begin{array}{c}\text { Rodzaj } \\
\text { controllingu }\end{array}$} & \multicolumn{1}{c|}{ Rola controllingu } \\
\hline $\begin{array}{l}\text { Controlling } \\
\text { finansowy }\end{array}$ & - Utrzymanie płynności finansowej. \\
& - Informacja o planowanej i rzeczywistej wartości przychodów i kosztów \\
& w układach kosztów: rodzajowych, kalkulacyjnych, miejsc powstawania \\
& kosztów, nośników kosztów. \\
& - Informacja o wartości planowanych i rzeczywiście udzielonych rabatów \\
& według segmentów rynku, regionów, pozycji asortymentowych. \\
& - Planowana i rzeczywista wartość należności i zobowiązań za dowolny \\
& okres i w żądanych przekrojach informacyjnych, np. według grup odbior- \\
& ców, dostawców. \\
& - Wartość należności i zobowiązań przeterminowanych. \\
& - Prognoza wpływu i wypływu środków pieniężnych. \\
& - Planowany i rzeczywisty rachunek przepływów środków pieniężnych. \\
& - Planowany i rzeczywisty rachunek zysków i strat oraz wskazanie odchyleń. \\
\hline Controlling & - Kontrola jakości dostarczanych do firmy towarów. \\
zaopatrzeniowy & - Kontrola, czy towary dotarły w odpowiednim czasie. \\
& - Nadzór nad zużyciem materiałów. \\
& - Kontrola kursów walut w przypadku zakupów na rynkach zagranicznych. \\
& - Dostarczanie informacji o korzystnych opustach cenowych, przy jednocze- \\
& Snej obserwacji rynku zaopatrzeniowego. \\
& $\begin{array}{l}\text { Powyższe działania pozwalają optymalizować zakupy zaopatrzeniowe } \\
\text { w przedsiębiorstwie. }\end{array}$ \\
\hline
\end{tabular}




\begin{tabular}{|c|c|}
\hline $\begin{array}{c}\text { Rodzaj } \\
\text { controllingu }\end{array}$ & Rola controllingu \\
\hline $\begin{array}{l}\text { Controlling } \\
\text { sprzedaży }\end{array}$ & $\begin{array}{l}\text { - Monitorowanie rynku i uwzględnianie jego tendencji podczas sterowania } \\
\text { przedsiębiorstwem. } \\
\text { - Bieżące sprawdzanie adekwatności, np. prowadzonej polityki cenowej czy } \\
\text { wyboru formy sprzedaży. } \\
\text { - Wykonywanie planu kosztów działu sprzedaży, aby później czuwać nad } \\
\text { jego realizacją. } \\
\text { - Określanie i wykorzystywanie mierników w celu sprawdzenia opłacalności } \\
\text { sprzedaży konkretnych towarów. } \\
\text { Przez powyższe działania zmierza się do osiągnięcia zakładanego wyniku. }\end{array}$ \\
\hline $\begin{array}{l}\text { Controlling } \\
\text { badawczy }\end{array}$ & $\begin{array}{l}\text { - Ustalanie asortymentu poszczególnych dóbr i usług z uwzględnieniem } \\
\text { przyszłych potrzeb klientów. } \\
\text { - Zaopatrywanie menedżerów w potrzebne informacje o wskaźnikach długo- } \\
\text { falowego zaangażowania zasobów finansowych. } \\
\text { - Dostarczanie informacji o korzyściach z dotychczas prowadzonych badań. } \\
\text { Działania w tym zakresie pozwalają przetrwać firmie w konkurencyjnym } \\
\text { otoczeniu. }\end{array}$ \\
\hline $\begin{array}{l}\text { Controlling } \\
\text { logistyki }\end{array}$ & $\begin{array}{l}\text { - Optymalizacja stanu zapasów magazynowych. } \\
\text { - Planowanie zakupów, transportu i wolumenu sprzedaży. } \\
\text { Wszystkie działania w tym zakresie mają się sprowadzać do zapewnienia } \\
\text { ciągłości rytmu zaspokajania potrzeb klientów przez koordynację działań } \\
\text { w poszczególnych podsystemach logistycznych. }\end{array}$ \\
\hline $\begin{array}{l}\text { Controlling } \\
\text { marketingu }\end{array}$ & $\begin{array}{l}\text { - Analiza dotychczasowej sprzedaży. } \\
\text { - Wspieranie działalności marketingowej i racjonalizacja jej kosztów. } \\
\text { - Dobór narzędzi marketingowych. } \\
\text { - Badanie prognoz dotyczących zapotrzebowania konsumentów. }\end{array}$ \\
\hline $\begin{array}{l}\text { Controlling } \\
\text { personalny }\end{array}$ & $\begin{array}{l}\text { - Planowanie i koordynacja zatrudnienia połączona z analizą } \\
\text { wykonania planu. } \\
\text { - Podnoszenie rentowności, sprawności i efektywności działań w obszarze } \\
\text { zarządzania zasobami ludzkimi. } \\
\text { - Powiązanie działań komórki personalnej z całym przedsiębiorstwem. } \\
\text { - Dbałość o przejrzystość kosztów personalnych i czynników je tworzących. } \\
\text { - Wskazywanie skutków pracy zasobów ludzkich w różnych obszarach funk- } \\
\text { cjonowania organizacji. } \\
\text { - Badanie potrzeb i kierunków zmian w systemie motywowania. } \\
\text { - Poszukiwanie dróg kompromisu między pracownikami a pracodawcą. } \\
\text { - Ewidencjonowanie poszczególnych składników kapitału ludzkiego. }\end{array}$ \\
\hline $\begin{array}{l}\text { Controlling } \\
\text { podatkowy }\end{array}$ & $\begin{array}{l}\text { - Planowanie procesów gospodarczych wpływających na obciążenia } \\
\text { podatkowe. } \\
\text { - Tworzenie źródeł informacji podatkowej wewnątrz organizacji. } \\
\text { - Tworzenie procedur służących do efektywnego planowania podatkowego. } \\
\text { - Budowa systemu weryfikacji prawidłowości rozliczeń. } \\
\text { - Analiza ryzyka i zagrożeń podatkowych. }\end{array}$ \\
\hline
\end{tabular}

Źródło: opracowanie własne na podstawie: Sekuła, 1999: 55-66; Ciesielski, 2001: 135; Długosz, 2004: 37; Sierpińska, 2004: 21; Zając, 2006: 205; Zając, 2008, za: Clark, 1996: 113; Urbanowicz, 2015: 26; Bytniewski, 2016: 80 
Cechą sprawnego systemu controllingu powinna być umiejętność przewidywania zachowania się rynku i kierunku jego rozwoju w przyszłości, co pozwoliłoby na podnoszenie zdolności konkurencyjnej przedsiębiorstwa w dalszym horyzoncie czasowym. Biorąc pod uwagę silną walkę konkurencyjną w sektorze handlu, istotne jest budowanie przewagi konkurencyjnej na podstawie marki, różnorodnego asortymentu, poziomu cen, lokalizacji, zakresu oraz jakości obsługi klienta i usług dodatkowych, wyposażenia placówek handlowych, zakresu i typu działań promocyjnych (Sławińska, 2008: 72), atmosfery i wyglądu placówki (Bilińska-Reformat, 2016: 19), a obecnie głównie przez kształtowanie wyróżniających, trudnych do skopiowania i pozyskania zasobów stanowiących naturalną barierę dostępu (Kuźniarska, 2018: 229).

\section{Bariery wdrażania controllingu identyfikowane w przedsiębiorstwach}

Samo wdrażanie controllingu wymaga przede wszystkim utworzenia w przedsiębiorstwie komórki, działu lub stanowiska zajmującego się realizacją controllingu (Weber, 2001: 3). Wiąże się to z koniecznością przekształcenia struktury organizacyjnej, w której należy uwzględnić nową komórkę organizacyjną controllingu, a w ślad za tym konieczne jest zatrudnienie lub wyłonienie spośród dotychczas zatrudnionych controllera, czyli osoby na nowo utworzone stanowisko (Walica, 2007: 172). Implementacja controllingu wiąże się ze zmianą stylu zarządzania (Błaszkowski, Szanser, 2011: 15), zwłaszcza z potrzebą zastosowania systemu motywacyjnego, a także zmianą systemu planistyczno-kontrolnego i związanego z tym systemu informacyjno-sprawozdawczego, który pozwala na raportowanie w różnych obszarach przedsiębiorstwa. Nieodzowna staje się zmiana systemu ewidencji księgowej oraz dokumentacji bieżącej związanej z prowadzaną działalnością gospodarczą. Wachlarz zmian obejmuje również techniczno-technologiczne opracowanie systemu informatycznego oraz budowę odpowiednich programów komputerowych (Walica, 2007: 172).

Występowanie barier przy wprowadzaniu zmian w organizacji identyfikuje się w czterech głównych obszarach: psychologicznym, wiedzy, organizacyjnym i finansowym (por. Tabela 2).

Problemy z implementacją controllingu wynikają między innymi z samego nazewnictwa - słowo controlling nieodzownie kojarzone przez pracowników z kontrolą, jest przyczyną występowania bariery psychologicznej, której przełamanie - według M. Sierpińskiej (2004: 42) - powoduje, iż pozostałe bariery stają się łatwiejsze do pokonania. 
Tabela 2. Klasyfikacja barier implementacji controllingu w sieciach handlowych

\begin{tabular}{|c|c|}
\hline Rodzaj barier & Opis \\
\hline Psychologiczne & $\begin{array}{l}\text { - Strach przed nowymi, nieznanymi rozwiązaniami } \\
\text { - Obojętność wobec zmian } \\
\text { - Niechęć do zmian - zarówno po stronie pracowników, jak i kadry } \\
\text { kierowniczej } \\
\text { - Brak chęci współpracy } \\
\text { - Działania sabotujące nowe rozwiązania } \\
\text { - Obawa przed ideą controllingu (utożsamianego z kontrolą) } \\
\text { - Strach przed utratą dotychczasowej swobody działania przez pracowników } \\
\text { - Obawa pracowników przed odpowiedzialnością } \\
\text { - Obawa przed oceną wykonywanej pracy } \\
\text { - Obawa przed ujawnieniem niekompetencji podczas wprowadzania zmian } \\
\text { - Trudności w zmianie dotychczasowych przyzwyczajeń pracowników } \\
\text { - Pogląd, iż koszty są niewspółmierne do wyników }\end{array}$ \\
\hline Wiedzy & $\begin{array}{l}\text { - Brak specjalistów z zakresu controllingu } \\
\text { - Niewielka wiedza z zakresu controllingu } \\
\text { - Brak osób posiadających kwalifikacje pozwalające na wdrożenie i nadzoro- } \\
\text { wanie funkcjonowania controllingu } \\
\text { - Trudności z naborem pracowników o odpowiednich kompetencjach } \\
\text { - Problemy z doborem odpowiednich wskaźników controllingu } \\
\text { - Postrzeganie instrumentów controllingu jako wysoce skomplikowanych } \\
\text { - Niska znajomość efektów wdrożenia controllingu } \\
\text { - Brak wiedzy na temat potrzeb i sposobu budowy systemu informacyjnego }\end{array}$ \\
\hline Organizacyjne & $\begin{array}{l}\text { - Konieczność przebudowy (rozbudowy) struktury organizacyjnej w związku } \\
\text { z utworzeniem komórki controllingu } \\
\text { - Niewłaściwe umiejscowienie controllera w strukturze organizacyjnej } \\
\text { - Niewłaściwie opisany zakres kompetencji controllera } \\
\text { - Brak odpowiednio wydzielonych kompetencji między komórkami organiza- } \\
\text { cyjnymi występującymi w organizacji } \\
\text { - Problem z powiązaniem zakresów uprawnień, odpowiedzialności i decyzyj- } \\
\text { ności kierowników komórek organizacyjnych } \\
\text { - Mocno zakorzenione i utrwalone w organizacji systemy zarządzania } \\
\text { - Problem z wyodrębnieniem centrów odpowiedzialności w organizacji } \\
\text { - Konieczność opracowania procedur związanych z obiegiem dokumentów } \\
\text { i informacji } \\
\text { - Brak odpowiednich systemów informatycznych } \\
\text { - Stosunkowo długi czas wdrażania } \\
\text { - Konieczność zmiany lub przebudowy systemu informacyjnego w przedsię- } \\
\text { biorstwie } \\
\text { - Konieczność zmian w systemach rachunkowości finansowej }\end{array}$ \\
\hline Finansowe & $\begin{array}{l}\text { - Koszty związane z projektowaniem wdrożenia controllingu } \\
\text { - Koszty pracy działu controllingu } \\
\text { - Koszty szkolenia pracowników } \\
\text { - Koszty usług zewnętrznych firm doradczych } \\
\text { - Zakup odpowiednich programów bądź licencji } \\
\text { - Zakup sprzętu komputerowego }\end{array}$ \\
\hline
\end{tabular}

Źródło: opracowanie własne na podstawie: Sierpińska, Niedbała, 2003: 65; Dynowska, 2005: 68; Nowak, 2013: 63; Goliszewski, 2015: 594; Nesterak, 2015: 112-117 


\section{Metodologia badań}

Przedmiotem badań była identyfikacja czynników stanowiących barierę wdrażania controllingu w sieciach handlu detalicznego. Badania przeprowadzono na przełomie 2016 i 2017 roku w centralach czterech dużych sieci handlowych zlokalizowanych w województwach małopolskim i wielkopolskim, prowadzących sieć supermarketów w całej Polsce, na próbie 204 celowo dobranych pracowników sieci handlowych (por. Tabela 3). W każdej z sieci handlowych w badaniu wzięło udział więcej niż 50 respondentów. Głównym kryterium doboru próby był rodzaj zajmowanego stanowiska (nie niższe niż specjalista w dziale). Łącznie do respondentów skierowano 250 kwestionariuszy ankiet, z czego część po przeprowadzeniu weryfikacji ich kompletności została odrzucona. Najliczniejszą grupę respondentów (84\%) stanowili specjaliści w działach, w tym specjaliści z działów controllingu, HR, zakupów, marketingu i kontroli, dalej kierownicy działów (8\%) oraz dyrektorzy (3\%).

Badania bezpośrednie przeprowadzono za pomocą kwestionariusza ankiety, zawierającego pytania zamknięte. Koncepcja badania dotyczącego implementacji controllingu przewidywała w pierwszej kolejności pytania o ocenę barier związanych z wdrażaniem controllingu (mierzonych w pięciostopniowej skali Likerta). W następnej kolejności w kwestionariuszu poproszono respondentów o ocenę preferowanej formy wdrożenia controllingu w przedsiębiorstwie. Weryfikacji poddano możliwość wdrożenia controllingu samodzielne lub za pomocą firmy consultingowej.

Tabela 3. Podział respondentów ze względu na zajmowane stanowisko w organizacji

\begin{tabular}{|l|c|c|}
\hline \multicolumn{1}{|c|}{$\begin{array}{c}\text { Rodzaj zajmowanego } \\
\text { stanowiska }\end{array}$} & $\begin{array}{c}\text { Liczba respondentów zajmujących } \\
\text { określone stanowisko }\end{array}$ & Odsetek badanych (\%) \\
\hline Specjalista w dziale & 172 & 84 \\
\hline Kierownik działu & 17 & 8 \\
\hline Dyrektor & 5 & 3 \\
\hline Inne (menedżerowie, księgowi) & 10 & 5 \\
\hline Razem & 204 & 100 \\
\hline
\end{tabular}

Źródło: opracowanie własne 


\section{Bariery controllingu w sieciach handlowych - wyniki badań}

Dla potrzeb realizacji badań empirycznych, na podstawie przeprowadzonych w polskich firmach produkcyjnych i usługowych badań dotyczących barier wdrażania controllingu, przyjęto następujące bariery wdrażania controllingu w przedsiębiorstwach handlowych:

1) koszty wdrożenia controllingu (bariera finansowa),

2) obawa pracowników przed zmianami (bariera psychologiczna),

3) brak odpowiednich rozwiązań informatycznych do prowadzenia controllingu (bariera organizacyjna),

4) długi czas wdrażania controllingu (bariera organizacyjna),

5) brak znajomości sposobów wprowadzania controllingu (bariera wiedzy),

6) brak opisanego procesu controllingu (bariera wiedzy),

7) brak znajomości odpowiednich instrumentów controllingu (bariera wiedzy).

Każda $\mathrm{z}$ ocenianych odpowiedzi przedstawiona została $\mathrm{w}$ tabeli zbiorczej (por. Tabela 4) oraz na rysunku (por. Rysunek 1), gdzie opis „nie mam zdania” oznacza, iż cechy mają charakter neutralny. Odpowiedzi „raczej się zgadzam” oraz „zdecydowanie się zgadzam” traktowane są jako potwierdzające występowanie bariery, natomiast „zdecydowanie się nie zgadzam” i „raczej się nie zgadzam" stanowią elementy zaprzeczające jej istnieniu.

Tabela 4. Bariery wdrażania controllingu w sieciach handlowych na podstawie oceny respondentów (\%)

\begin{tabular}{|l|l|c|c|c|c|c|}
\hline & Rodzaj bariery & $\begin{array}{c}\text { Zdecydowanie } \\
\text { się zgadzam }\end{array}$ & $\begin{array}{c}\text { Raczej się } \\
\text { zgadzam }\end{array}$ & $\begin{array}{c}\text { Nie mam } \\
\text { zdania }\end{array}$ & $\begin{array}{c}\text { Raczej się } \\
\text { nie zgadzam }\end{array}$ & $\begin{array}{c}\text { Zdecydowanie } \\
\text { się nie } \\
\text { zgadzam }\end{array}$ \\
\hline 1 & $\begin{array}{l}\text { Koszty wdrożenia } \\
\text { controllingu }\end{array}$ & 30 & 43 & 19 & 6 & 2 \\
\hline 2 & $\begin{array}{l}\text { Obawa } \\
\text { pracowników } \\
\text { przed zmianami }\end{array}$ & 29 & 43 & 14 & 11 & 3 \\
\hline 3 & $\begin{array}{l}\text { Brak } \\
\text { odpowiednich } \\
\text { rozwiązań } \\
\text { informatycznych }\end{array}$ & 20 & 35 & 34 & 7 & 4 \\
\hline 4 & $\begin{array}{l}\text { Długi czas } \\
\text { wdrażania }\end{array}$ & 28 & 15 & 38 & 9 \\
\hline 5 & $\begin{array}{l}\text { Brak znajomości } \\
\text { sposobów } \\
\text { wprowadzania } \\
\text { controllingu }\end{array}$ & 28 & 17 & 7 & 2 \\
\hline
\end{tabular}




\begin{tabular}{|l|l|c|c|c|c|c|}
\hline & Rodzaj bariery & $\begin{array}{c}\text { Zdecydowanie } \\
\text { się zgadzam }\end{array}$ & $\begin{array}{c}\text { Raczej się } \\
\text { zgadzam }\end{array}$ & $\begin{array}{c}\text { Nie mam } \\
\text { zdania }\end{array}$ & $\begin{array}{c}\text { Raczej się } \\
\text { nie zgadzam }\end{array}$ & $\begin{array}{c}\text { Zdecydowanie } \\
\text { się nie } \\
\text { zgadzam }\end{array}$ \\
\hline 6 & 33 & 44 & 16 & 4 & 3 \\
$\begin{array}{l}\text { Brak } \\
\text { opracowanego } \\
\text { procesu wdrażania } \\
\text { controllingu }\end{array}$ & 31 & 50 & 11 & 6 & 2 \\
\hline 7 & $\begin{array}{l}\text { Brak znajomości } \\
\text { odpowiednich } \\
\text { instrumentów } \\
\text { controllingu }\end{array}$ & & & & & \\
\hline
\end{tabular}

Źródło: opracowanie własne

Analizując wyniki badań, należy zauważyć, iż najczęściej wskazywanymi przez respondentów barierami wdrażania controllingu w sieciach handlowych są bariery wiedzy (pozycje 5-7 w Tabeli 4), których występowanie zadeklarowało w każdym przypadku łącznie (odpowiedzi „,raczej się zgadzam” oraz ,zdecydowanie się zgadzam") ponad 75\% respondentów. Na podobnym poziomie respondenci ocenili koszty implementacji controllingu (pozycja 1 - łącznie 73\%), a więc barierę finansową, oraz barierę psychologiczną (pozycja 2 - łącznie 72\%) - związaną z obawą pracowników przed zmianami. W przypadku oceny czasu wdrażania controllingu większa część respondentów (łącznie 47\% odpowiedzi „,raczej się nie zgadzam” oraz ,zdecydowanie się nie zgadzam”) zadeklarowała, iż czas nie stanowi bariery przy implementacji controllingu. Szczegółowy rozkład wyników zaprezentowano na Rysunku 1.

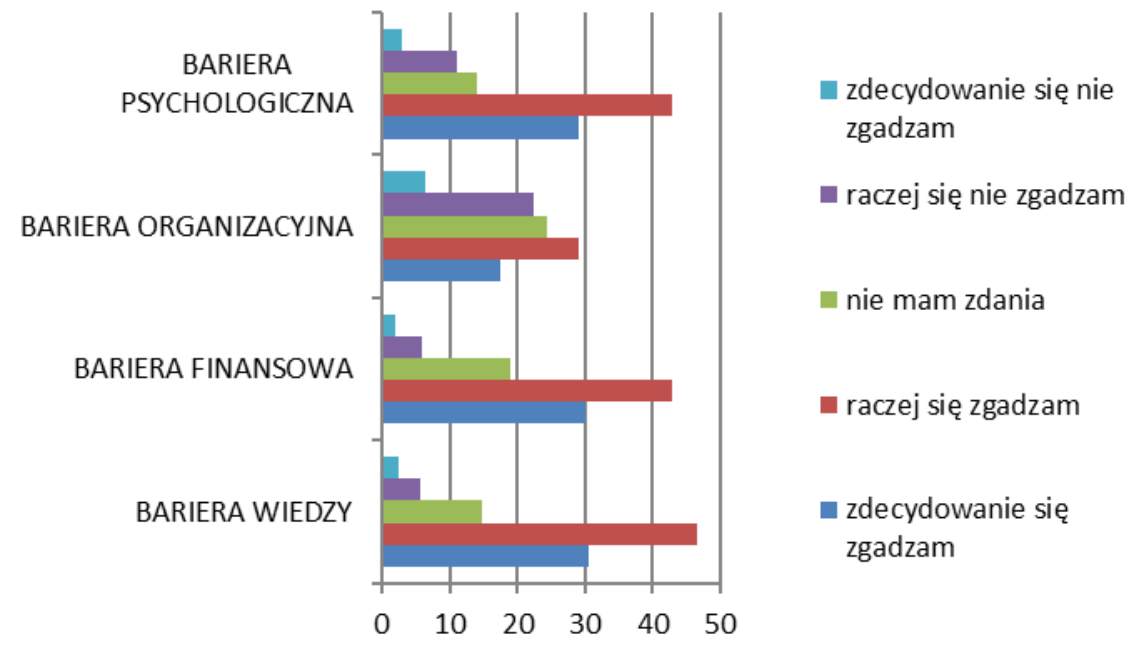

Rysunek 1. Struktura odpowiedzi respondentów na temat barier wdrażania controllingu Źródło: opracowanie własne 
Uzyskane w badaniu dane poddano analizie z uwzględnieniem pochodzenia kapitału badanych sieci handlowych (por. Tabela 5). Było to istotne ze względu na fakt, iż controlling nie jest szeroko stosowany w polskich przedsiębiorstwach - częściej znajduje zastosowanie w organizacjach z udziałem kapitału zagranicznego.

Tabela 5. Ocena barier wdrażania controllingu w sieciach handlowych z uwzględnieniem rodzaju kapitału (\%)

\begin{tabular}{|l|c|c|c|c|c|}
\hline Rodzaj sieci handlowej & $\begin{array}{c}\text { Zdecydowanie } \\
\text { się nie zgadzam }\end{array}$ & $\begin{array}{c}\text { Raczej } \\
\text { się nie } \\
\text { zgadzam }\end{array}$ & $\begin{array}{c}\text { Nie } \\
\text { mam } \\
\text { zdania }\end{array}$ & $\begin{array}{c}\text { Raczej się } \\
\text { zgadzam }\end{array}$ & $\begin{array}{c}\text { Zdecydowanie } \\
\text { się zgadzam }\end{array}$ \\
\hline \multicolumn{7}{|c|}{ Koszty wdrożenia controllingu } \\
\hline Z kapitałem polskim & 2 & 7 & 21 & 36 & 34 \\
\hline Z kapitałem zagranicznym & 0 & 4 & 18 & 51 & 27 \\
\hline \multicolumn{7}{|c|}{ Obawa pracowników przed zmianami } \\
\hline Z kapitałem polskim & 4 & 15 & 16 & 41 & 24 \\
\hline Z kapitałem zagranicznym & 2 & 7 & 12 & 45 & 34 \\
\hline \multicolumn{6}{|c|}{ Brak odpowiednich rozwiązań informatycznych } \\
\hline Z kapitałem polskim & 4 & 7 & 31 & 35 & 23 \\
\hline Z kapitałem zagranicznym & 1 & 7 & 40 & 35 & 17 \\
\hline \multicolumn{7}{|c|}{ Długi czas wdrażania } \\
\hline Z kapitałem polskim & 6 & 47 & 13 & 28 & 6 \\
\hline Z kapitałem zagranicznym & 13 & 30 & 17 & 17 & 23 \\
\hline \multicolumn{6}{|c|}{ Brak znajomości sposobów wprowadzania controllingu } \\
\hline Z kapitałem polskim & 1 & 4 & 19 & 39 & 37 \\
\hline Z kapitałem zagranicznym & 1 & 8 & 19 & 54 & 18 \\
\hline \multicolumn{7}{|c|}{ Brak opracowanego procesu wdrażania controllingu } \\
\hline Z kapitałem polskim & 4 & 3 & 12 & 38 & 43 \\
\hline Z kapitałem zagranicznym & 0 & 7 & 9 & 43 & 40 \\
\hline \multicolumn{7}{|c|}{ Brak znajomości odpowiednich instrumentów controllingu } \\
\hline Z kapitałem polskim & 2 & 7 & 15 & 55 & 21 \\
\hline Z kapitałem zagranicznym & 1 & 7 & 9 \\
\hline
\end{tabular}

Źródło: opracowanie własne

Biorąc pod uwagę podział sieci handlowych według rodzaju kapitału, okazuje się, że respondenci zatrudnieni w sieciach handlowych z udziałem polskiego kapitału jako największe przeszkody w implementacji controllingu wskazują bariery wiedzy - brak opracowanego procesu wdrażania controllingu (81\%) oraz brak znajomości sposobów wprowadzania controllingu (76\%) i brak znajomości odpowiednich instrumentów controllingu (76\%).

W przypadku sieci z udziałem kapitału zagranicznego ankietowani wskazali jako najistotniejsze przeszkody: brak znajomości odpowiednich instrumentów controllingu (83\%), obawy pracowników przed zmianami (79\%) oraz koszty wdrożenia (78\%). 
Przy okazji oceny barier wdrażania controllingu zapytano respondentów o preferowany sposób wdrażania controllingu - chodziło o zdefiniowanie, czy controlling powinien być wdrażany przez sieci handlowe samodzielnie, czy przy udziale zewnętrznych firm consultingowych. Przeprowadzona analiza pozwoliła ustalić, iż za samodzielną formą implementacji controllingu opowiedziało się $62 \%$ respondentów. Jest to zaskakujący wynik ze względu na deklarowane w pierwszej części badania bariery związane z brakiem wiedzy na temat instrumentów i sposobów implementacji controllingu.

\section{Podsumowanie}

Sieci handlowe stojące w obliczu zmiennego, turbulentnego otoczenia, dużej konkurencyjności na rynku oraz braku lojalności klientów, zmuszone są do poszukiwania sposobów skutecznego zarządzania w różnych obszarach swojego funkcjonowania, związanych nie tylko z samą sprzedażą, ale również z logistyką, marketingiem, finansami czy zarządzaniem personelem. Controlling to nowoczesny, kompleksowy, ułatwiający sprawne zarządzanie proces dostarczający informacji pozwalających na sprawne i trafne podejmowanie decyzji. Racjonalne korzyści wynikające z szerokiego zastosowania controllingu w sieciach handlowych nie są powszechnie znane, a brak tej wiedzy stanowi jedną z przeszkód w podejmowaniu działań wdrożeniowych.

Badania wskazują, iż jedną z najistotniejszych przeszkód przy implementacji controllingu w sieciach handlowych jest bariera wiedzy. Zbyt niska świadomość użyteczności controllingu wśród menedżerów, brak narzędzi (wskaźników ilościowych i jakościowych) dedykowanych dla sieci handlowych, konieczność adaptacji narzędzi (takich jak analiza ABC, XYZ, SWOT, benchmarking, zarządzanie przez cele) z innych obszarów zarządzania, to tylko niektóre z powodów występowania wspomnianej bariery. Okazuje się, iż równie ważne jak odpowiednia wiedza na temat controllingu jest właściwe przygotowanie sieci handlowych do jego implementacji - zarówno pod względem zaplecza finansowego, jak i z uwzględnieniem punktu widzenia pracowników, co niewątpliwie wykazały przedstawione wyniki badań.

Realizacja badania empirycznego w sieciach handlowych stanowi dla badacza wyzwanie, głównie ze względu na hermetyczność środowiska i ograniczony dostęp do respondentów. Jego przeprowadzenie wymaga wielomiesięcznych pertraktacji, konsultowania kwestionariuszy ankiety z menedżerami wyższego szczebla oraz prowadzenia badań pilotażowych. Niemniej efekty pracy stanowią wkład w naukę dotychczas niezbadanych na polskim gruncie wybranych obszarów działalności sieci handlowych. 


\section{Bibliografia}

Bieńkowska A., Kral Z., Zabłocka-Kluczka A. (2017), Stan, bariery i przesłanki wdrożenia controllingu strategicznego - wyniki badań ogólnopolskich, „Prace Naukowe Uniwersytetu Ekonomicznego we Wrocławiu", nr 471, s. 47-59, https://doi.org/10.15611/pn.2017.471.04.

Bilińska-Reformat K. (2016), The role of dynamic marketing capabilities in creation of competitive advantage of commercial chains, „Handel Wewnętrzny”, nr 4(363), s. 16-24.

Błaszkowski G., Szanser P. (2011), Wdrażanie controllingu w dojrzatych organizacjach. Jak przezwyciężyć opory?, „Controlling - Wiedza i Narzędzia Praktyczne”, s. 14-23.

Bytniewski A. (2016), Podsystem controllingu $w$ ramach zintegrowanego systemu zarzadzania jako źródło informacji na potrzeby rachunkowości zarządczej i controllingu, „Prace Naukowe Uniwersytetu Ekonomicznego we Wrocławiu", nr 440, s. 72-82.

Ciesielski M. (2001), Logistyka w tworzeniu przewagi konkurencyjnej firmy, Wydawnictwo Akademii Ekonomicznej w Poznaniu, Poznań.

Clark T. (1996), European Human Management, Blackwell Business, Oxford.

Długosz A. (2004), Controlling działalności badawczo-rozwojowej, [w:] M. Sierpińska (red.), Controlling funkcyjny w przedsiębiorstwie, Oficyna Ekonomiczna, Kraków, s. 37-66.

Dynowska J. (2005), Problemy wdrażania controllingu w przedsiębiorstwach województwa warmińsko-mazurskiego, „Prace Naukowe Akademii Ekonomicznej we Wrocławiu”, nr 1080, s. $68-77$.

Dynowska J. (2015), Czynniki ograniczajace wdrażanie controllingu w świetle badań ankietowych, „Prace Naukowe Uniwersytetu Ekonomicznego we Wrocławiu”, nr 399, s. 169-175, http://doi. org/10.15611/pn.2015.399.15.

Dynowska J., Kes Z. (2016), Oczekiwane bariery, przesłanki i efekty wdrożenia controllingu w gminach w świetle badań ankietowych, „Prace Naukowe Uniwersytetu Ekonomicznego we Wrocławiu", nr 440, s. 170-179.

Eschenbach R. (1990), Stand des Controlling in Österreich, [w:] E. Mayer, J. Weber (red.), Handbuch Controlling, C.E. Poeschel Verlag, Stuttgart, s. 671-684.

Fjałkowska D. (2013), Korzyści i bariery funkcjonowania controllingu - teoria, praktyka, wyniki badań, „Prace Naukowe Wałbrzyskiej Wyższej Szkoły Zarządzania i Przedsiębiorczości”, nr 21, s. 63-82, http://www.pracenaukowe.wwszip.pl/prace/prace-naukowe-21.pdf [dostęp: 20.05.2019].

Goliszewski J. (2015), Controlling - koncepcje, zastosowania, wdrożenie, Oficyna Wolters Kluwer business, Warszawa.

Horvath P. (2006), Controlling, Verlag Vahlen, München.

https://www.icv-controlling.com/pl/o-controllingu/co-to-jest-controlling.html [dostęp: 20.05.2019].

Janczyk-Strzała E. (2013), Perspektywy, bariery i możliwości rozwoju controllingu w uczelniach niepublicznych w świetle wyników badań, „Prace Naukowe Uniwersytetu Ekonomicznego we Wrocławiu", nr 291, s. 178-187.

Kowalewski M., Lelusz H. (2018), Przesłanki, bariery i efekty wdrożenia controllingu w opinii kadry menedżerskiej na przykładzie Miejskiego Przedsiębiorstwa Energetyki Cieplnej, „Studia Oeconomica Posnaniensia", t. 6, nr 8, s. 5-16, http://doi.org/10.18559/SOEP.2018.8.1.

Kuźniarska A. (2018), Pozacenowe czynniki konkurencyjności sieci handlowych na podstawie oceny ich pracowników, „Przedsiębiorczość i Zarządzanie”, t. XIX, z. 9, cz. III, s. 221-236.

Nesterak J. (2015), Controlling zarzadczy - projektowanie i wdrażanie, Oficyna Wolters Kluwer business, Warszawa.

Nowak M. (2013), Controlling w zarządzaniu. Uwarunkowania psychologiczne, Wydawnictwo Uniwersytetu Ekonomicznego we Wrocławiu, Wrocław.

Reichmann T. (2006), Controlling mit Kennzahlen, Verlag Vahlen, München.

Rynek wewnętrzny w 2017 r. Analizy statystyczne (2018), GUS, Warszawa. 
Sekuła Z. (1999), Controlling personalny, część 1. Istota i przedmiot controllingu personalnego, Oficyna Wydawnicza Ośrodka Postępu Organizacyjnego Sp. z o.o., Bydgoszcz.

Seufert B. (2014), Konsolidierung im Handel und die Bedeutung für das Controlling, [w:] M. Buttkus, R. Eberenz, Controlling in der Konsumgüterindustri. Innovative Ansätze und Praxisbeispiele, Springer Gabler, Wiesbaden, s. 47-68, https://doi.org/10.1007/978-3-658-04946-1.

Sierpińska M. (2004), Controlling funkcyjny w przedsiębiorstwie, Oficyna Ekonomiczna, Kraków. Sierpińska M., Niedbała B. (2003), Controlling operacyjny w przedsiębiorstwie, Wydawnictwo Naukowe PWN, Warszawa.

Sławińska M. (2008), Kompendium wiedzy o handlu, Wydawnictwo Naukowe PWN, Warszawa.

Urbanowicz P. (2015), Controlling podatkowy - skuteczne zarzadzanie podatkiem od towarów i ustug, „Zeszyty Naukowe Uniwersytetu Szczecińskiego”, nr 864, „Finanse, Rynki Finansowe, Ubezpieczenia", nr 76, t. 1, s. 23-33, http://www.wneiz.pl/nauka_wneiz/frfu/76-2015/ FRFU-76-t1-23.pdf [dostęp: 28.12.2018].

Vollmuth H. (2007), Controlling. Planowanie, kontrola, kierowanie, Placet, Warszawa.

Walica H. (2007), Inwestycje i controlling w przedsiębiorstwie, Wydawnictwo Wyższej Szkoły Biznesu w Dąbrowie Górniczej, Dąbrowa Górnicza.

Weber J. (2001), Wprowadzenie do controllingu, Oficyna Controllingu Profit, Katowice.

Zając P. (2006), Controlling personalny w zarządzaniu kapitatem ludzkim, ,Zeszyty Naukowe Polskiego Towarzystwa Ekonomicznego", nr 4, s. 199-217.

Zając P. (2008), Teoretyczne aspekty controllingu personalnego, „Zeszyty Naukowe Uniwersytetu Ekonomicznego w Krakowie”, nr 784, s. 107-121.

\title{
Barriers of Implementation of Controlling in the Retail Chains
}

\begin{abstract}
The main goal of the conducted research was to identify the factors constituting a barrier to the implementation of controlling in the retail chains. Quantitative research was carried out using a research tool, which was a questionnaire, containing closed questions addressed to employees of retail chains, mainly specialists from controlling departments, HR, managers at various levels and directors. The research was carried out in large networks with the participation of Polish and foreign capital. The results of the research have shown that the most important barrier to the implementation of controlling is the too low level of knowledge in organizations on how to implement it and the lack of adequate financial resources enabling its implementation.

Due to the tightness of retail chains and the fact that up to now there were mainly barriers to the implementation of controlling in production and service units, the topic discussed in the study was considered important.
\end{abstract}

Keywords: barriers of implementation, controlling, retail chains

JEL: D22, M42 


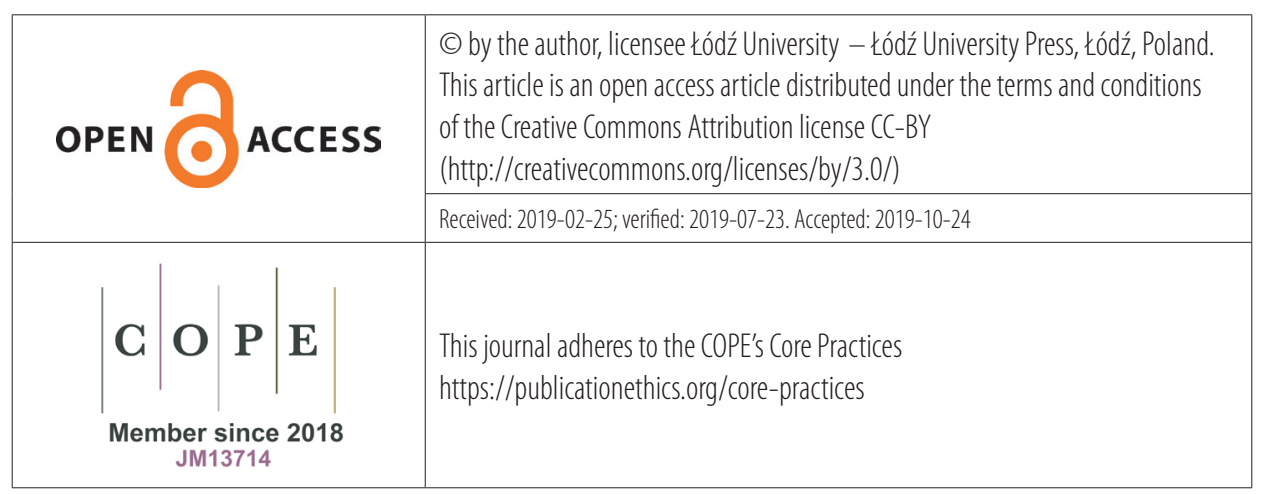

